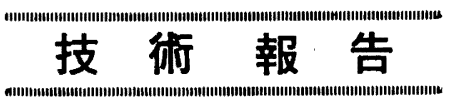

UDC $621.69: 538.4: 621.646 .3$

\title{
電磁ポンプによる溶融金属の流量制御に関する研究*
}

\author{
千々岩健児 ${ }^{* *}$. 伊藤 光男***。野呂 克彦****
}

\section{A Study of Flow Rate Control of Molten Metals by Electromagnetic Pump}

Kenji Chyjiwa, Mitsuo Iтo, and Katsuhiko Noro

\begin{abstract}
Synopsis:
The flow rate control of molten metal was investigated by means of a pair of 3 phase $200 \mathrm{~V}$ flat type linear induction electromagnetic pumps.

Two pumps of each capacity 11.5 KVA were placed at both sides of the vertical nozzle and were operated to induce the force in the direction opposite to the free falling of the metal.

The molten metals used were $\mathrm{Al}$ alloy and cast iron.

For $\mathrm{Al}$ alloy, the flow rate decreased from $1.20 \mathrm{Kg} / \mathrm{sec}$ to $0.83 \mathrm{Kg} / \mathrm{sec}$ by increasing the input voltage from 0 to $200 \mathrm{~V}$, resulting in the maximum control of the molten metal flow rate of $30 \%$.

For cast iron, the power output of the pumps was not sufficient to control the flow rate, because of the lower electrical-conductivity of cast iron as compared with $\mathrm{Al}$ alloy.

These results were confirmed theoretically, and the data necessary for design of electromagnetic pump were obtained.
\end{abstract}

(Received July 17, 1971)

\section{1. 緒言}

一般の鋳造工程において，省力化および品質管理など の面から，鋳造作業全体の自動化および連続化一の要求 が急速に高まつている.これを注湯工程について見る と, 溶湯の輸送, 適正分配および注湯の自動化，さらに は溶湯の流量および鋳込量の適確な制御が不可欠のもの となつている. 従来でも遠心ポンプのごとき機械的ボン プ，立たガス压による压送を利用した溶湯輸送の試み はあるが，高融点の金属に対しては，構造の複雑さ，装 置の耐久性の問題，および流量制御の不安定性などの面 からいまだ実用化されていない，そこで無接触の状態で 溶湯に力を作用させることができ，構造および保守も簡 単で，かつ制御を電気的に行なえる電磁式流量制御方式 がにわかに注目され，最近これに関する研究がソ連など を中心に進められている1 フ。かし電磁式流量制御方 式の中心ともなるべき電磁ポンプの動作特性, 流量制御 特性などについては, 彷来の内外の研究報告をみてもい まだ満足なものが得られていない，そこで本研究では平 面型直線誘導電磁ポンプを試作し，溶融金属としてラウ タル $(1 \cdot 40 \% \mathrm{Cu}, 6 \cdot 99 \% \mathrm{Si}-\mathrm{Al}$ 合金）を用いて流量制御
特性を求め, 西わせて電磁ホンフの泠却方法, 据付環境 への適応性などについて研究した・・の結果をもとにし て電磁式流量制御方式のたて型連続鋳造機への応用の可 能性を検討した.

本論交ではまず試作した電磁ホンプの構造について述 ベ，ついで本ボンフの強さを示吉磁束密度の測定結果, ならびにこの磁束内に固体金属をおいた場合のポンプ特 性試験結果を述べ，最後にこのポンプを用いて溶融金属 の流量制御を行なつた試験について報告する。

\section{2. 試作した電磁ポンプの構造}

Photo. 1 および Fig. 1 は試作した電磁ポンプの構造 を示す. 高さ $120 \mathrm{~mm} \times$ 幅 $550 \mathrm{~mm}$ ×厚さ $0.35 \mathrm{~mm} \mathrm{の}$ 珪素鋼板に, 深さ $70 \mathrm{~mm} \times$ 幅 $14 \mathrm{~mm}$ の溝を切り, これ を 300 板重ね合わせて厚さ的 $100 \mathrm{~mm}$ とした櫛形のブ ロックを作り，この溝に $2 \mathrm{~mm} \phi$ の銅線を 1 相につき

* 昭和45年10月本会誹演大会にて発表 昭和 46 年 7 月 17 日受付

** 東京大学工学部 工博

*** 東京大学工学部

**** 新日本製鉄 (株) 名古屋製鉄所 


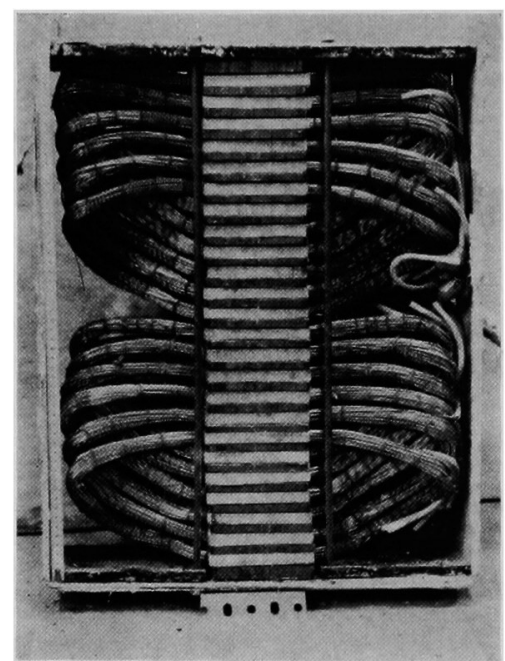

Photo. 1. Test electromagnetic pump.

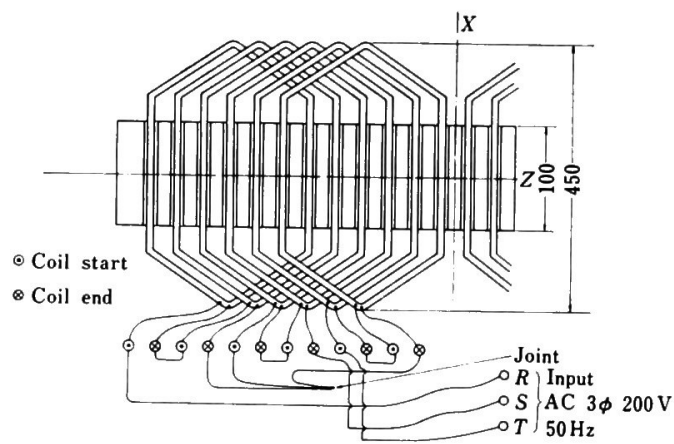

Fig. 1. Schematic drawing of test-fabricated electromagnetic pump.

180 回埋め込み $\mathrm{Y}$ 結線とした.なお全長 $550 \mathrm{~mm}$ を 2 分 し，おのおのが 2 極となるように捲線を行なつた。

Table 1 はこの誘導電磁ポンプの明細を示す. 定格は 3 相 $200 \mathrm{~V} 50 \mathrm{H}_{\mathrm{z}}$ で, 3 相スライダックトランスにより 0〜200V に可変できるようにした. 電磁ポンプ本体はは 断熱材によるカバーで覆い周囲の熱を遮断できる構造を とつた・またカバー内部へブロワーで送風し強制冷却を 行なうようにした. Fig. 1 に示した電磁ポンプ 2 基を平 行にならべて 1 ユニットとし，これら 2 基のコア両面間 は一定の間隔をあけた。 そしてその間に，溶湯を流す， ズルまたは試験用の板を設置できるようにした。 また平 面型直線誘導電磁ポンプ特有の力率低下を防ぐために, 進相コンデンサによつて力率改善をはかつた。
Table 1. Specification of electromagnetic pump.

\begin{tabular}{l|l}
\hline \multicolumn{1}{c|}{ Type } & $\begin{array}{l}\text { Flat-type linear } \\
\text { induction pump }\end{array}$ \\
\hline Input & 3 phase, 200 V, \\
Capacity & $50 \mathrm{~Hz}$ \\
Total weight (per pump) & $71 \cdot 5 \mathrm{KVA} \times 2$ \\
Weight of copper coil & $32 \cdot 4 \mathrm{~kg}$ \\
Breadth of core & $100 \mathrm{~mm}$ \\
Length of core & $550 \mathrm{~mm}$ \\
Thickness of core plate & $0.35 \mathrm{~mm}$ \\
& $2 \mathrm{~mm} \phi$ copper \\
Material of coil & wire insulated \\
Pole No & 4 \\
Pole pitch & $132 \mathrm{~mm}$ \\
Turn No (per phase, per pole) & 180 \\
Connection & Star \\
\hline
\end{tabular}

\section{3. 磁束密度測定試験}

\section{$3 \cdot 1$ 試験方法}

Fig. 2 に示すように 2 基の電磁ポンプを対面配置し, ガウスメータを用いて両ポンプ間隙中央部（軸方向, 図 中の $\mathrm{Z}$ 軸方向), および各ポンプのコア表面について各 点の磁束密度を測定した. 両ポンプ間隙は $80 \mathrm{~mm}$ とし, 入力電压は $50,100,150,200 \mathrm{~V}$ とた。

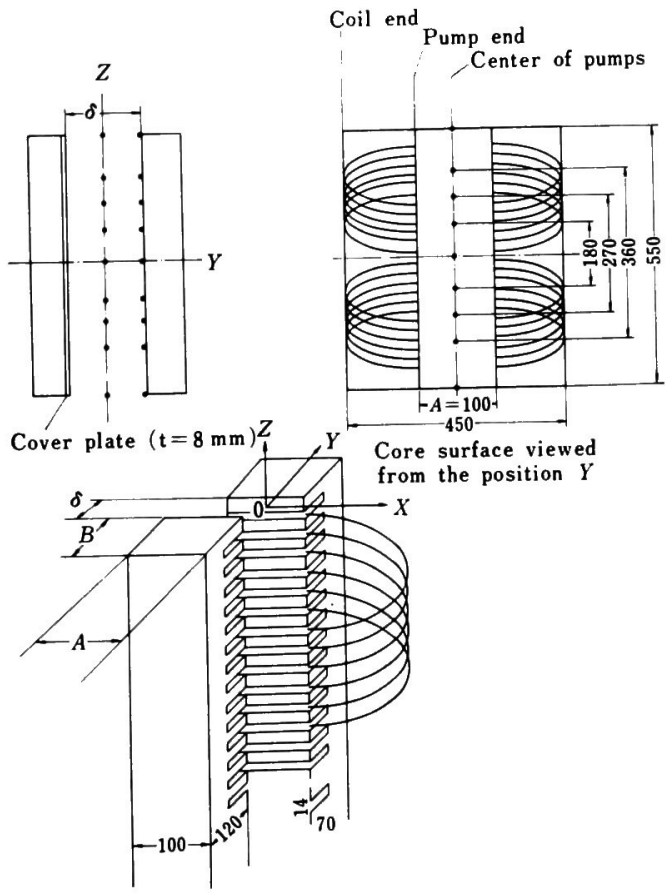

Fig. 2. Positions measured magnetic flux density. 


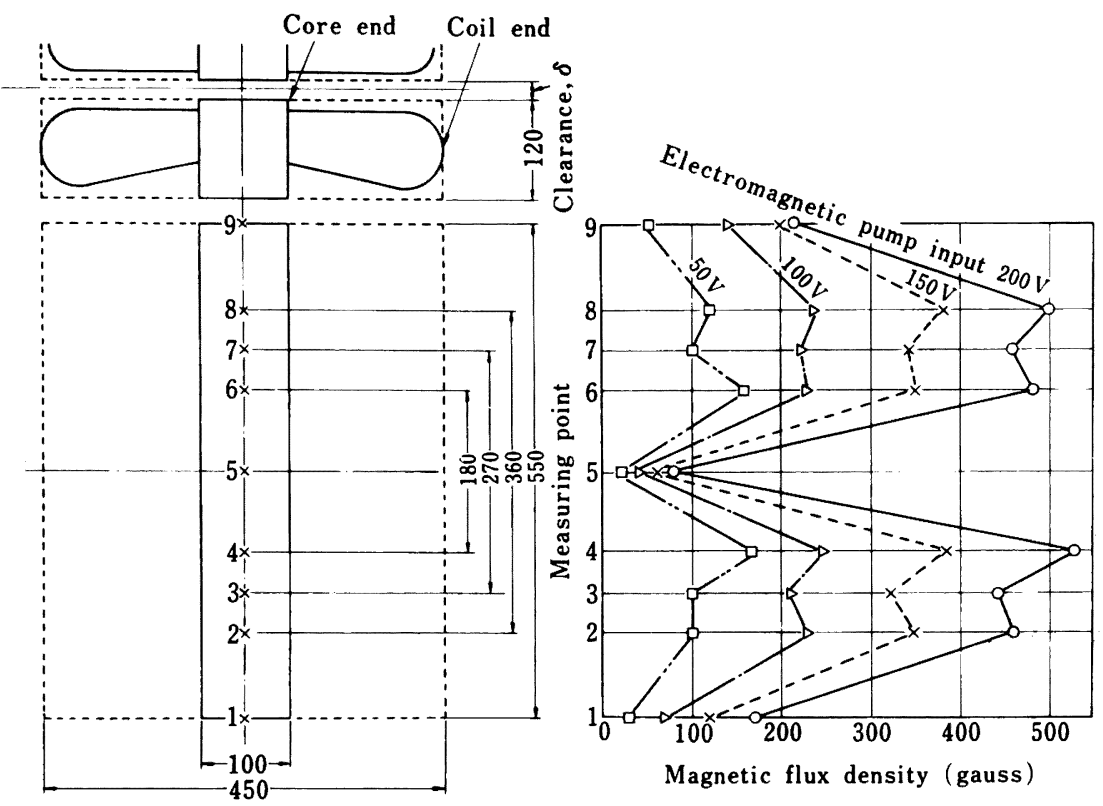

Fig. 3. Relation between measuring point and magnetic flux density.

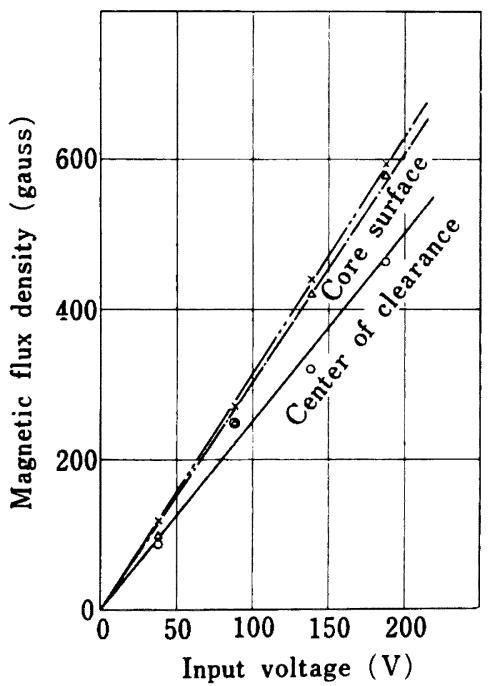

Fig. 4. Magnetic flux density at the center of the clearance and at the core surface.

\section{2 測定結果}

Fig. 3 は間隙中央 $\mathrm{Z}$ 軸上の磁束密度分布の測定結果を 示寸. 本試作の電磁ポンプは 4 極のため, 磁束密度は 2 つの波が生じ中央部 $(Z=0$ 点) で磁束密度が急激に減 少し, 節の部分があらわれた. また磁束密度振幅值と入
力電仕はほぼ比例する傾向を示した. ポンプの間陌中央 部とポンプコア表面の磁束密度を比較すると Fig. 4 に 示すように中央部はコア表面より的 $20 \%$ 程度磁束密度 が小さくなつていた. またポンプ幅方向の磁束密度は Fig. 5 に示すように中心付近は大きく, 両側へ遠ざかる にしたがい小さく, 捲線末端で 10２0 ガウス程度であ つた・波形自体に大きな不均一性の存在する理由は，こ の種の電磁ポンプ特有の縦端効果, 横端効果などの諸効 果の影響ならびに多数のスロットの存在などによる構造 上の問題が考えられる.

\section{4. 固体金属による電磁ポンプ特性試験}

\section{1 試釦方法}

電磁ポンプを溶湯に適用する前记電磁力作用体として 厚さ $15 \mathrm{~mm}$ および $10 \mathrm{~mm}$ のアルミニウム板（幅 100 $\mathrm{mm} \times$ 長さ $1000 \mathrm{~mm}$ ) を用いて発生力の特性試験を行 なつた. Fig. 6 に実験装置の概要を示す. 電磁ポンプを 対面配置し, 両コア間, 間隙中心にアルミニウム板を配 置した，上端にはばね科を取りつけ，位置設定と回転を 防ぐため側面を上下各 4 個のガイドローラで支持した. 両ポンプの間隙を $15,42,80 \mathrm{~mm}$ と 3 種類に, また電 磁ポンプの入力電死を $50,100,150,175,200 \mathrm{~V}$ にか え, ポンプの間陌と入力電圧の変化に対する発生力の特 性をばね秤によつて検出した。 


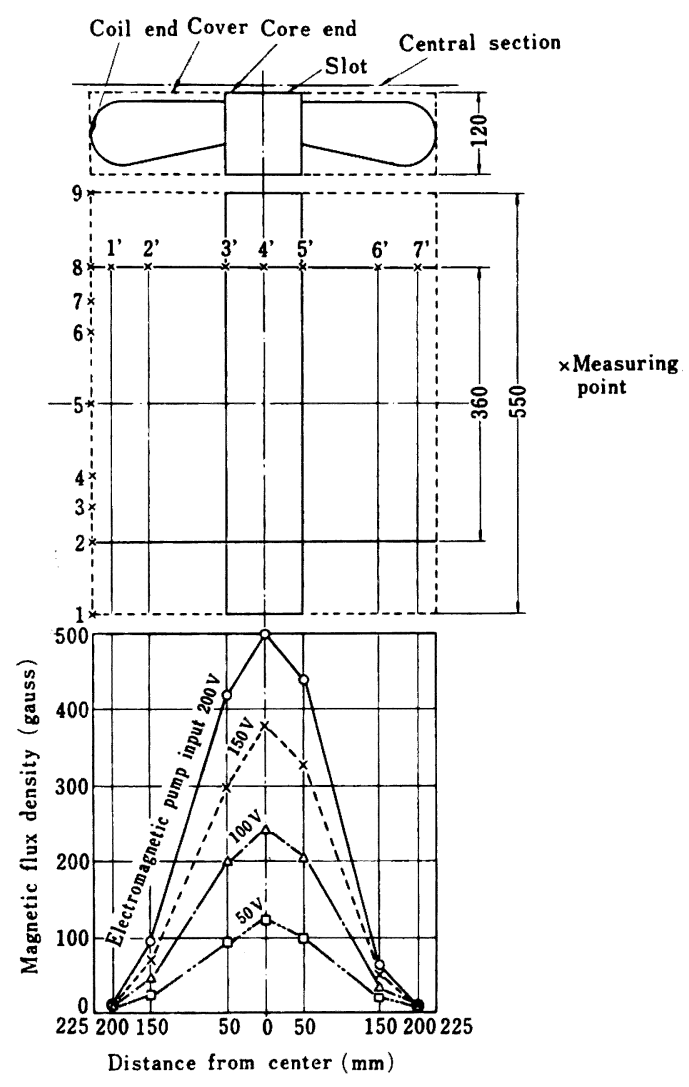

Fig. 5. Relation between magnetic flux density and distance from center.

\section{2 試験結果}

Fig. 7 に間隙を 15，42，80 mm にしたとき，Fig. 8 に板厚を $10,15 \mathrm{~mm}$ に変えたときの雷磁ホンプ入力電 正と発生力の特性曲線を示す、いずれも発生力は電磁ポ ンプ入力電压のほほ 2 乘に比例して增加している.これ は

（1）発生力は磁束密度の 2 乘に比例与る.\$*

(2) 磁束密度は電磁ポンプ入力電压に比例する.

ことからおこるものと考えられる.この結果から, 本夕 イプのような電磁ホンプについては, 出力制御を電压制 御で行なう際, 入力電圧の低い所で使用するのはあまり 有効でないと推定される。 また, 本実験では電磁ポンプ の間隙を 3 種類変化させて測定を行なつているが，Fig. 7 に明らかなように，ポンプの間隙の大小によつて発生 力が大きく変わることがわかる. 磁束密度分布と動力測 定では電磁ボンプの泠却は行なわなかつたが，捲線部に 多少の温度上昇が留められただけで問題にならなかつ た。

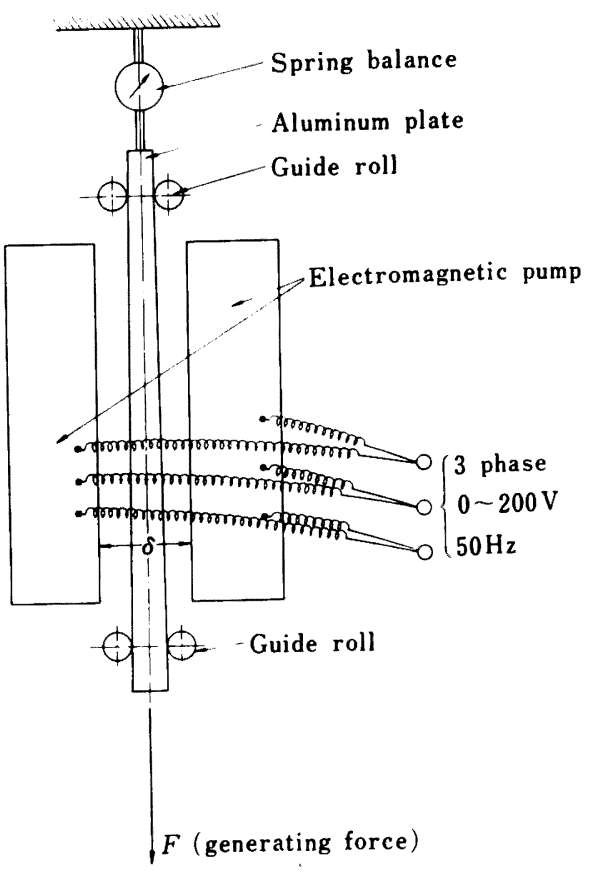

Fig. 6. Schematic drawing of equipment for examination of properties of electromagnetic pump.

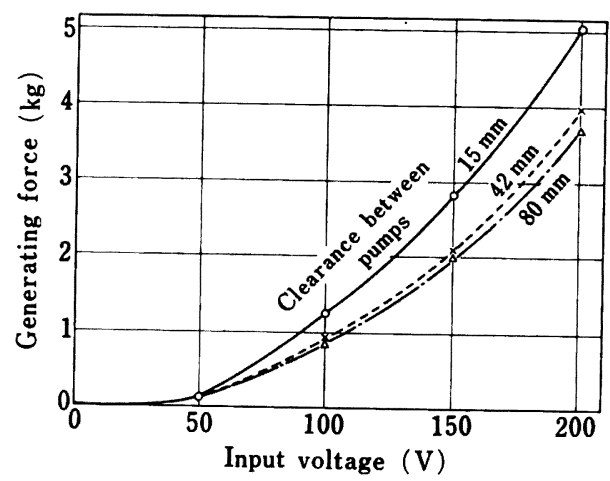

Fig. 7. Relationship between input voltage and generating force for varying clearance (aluminum sheet, $10 \mathrm{~mm}$ ).

\section{5. 流量制御特性試験}

\section{$5 \cdot 1 \cdot$ 試験方法}

以上の基礎的な諸特性試験終了後, 溶融金属としてラ ウタル（化学成分を Table 2 に, 物性值を Table 3 亿 示す）を用い，電磁ポンプの流量制御特性試験を行なつ た. Fig. 9 に実験装置概要を示す.ノズルは断面が内の り $15 \mathrm{~mm} \times 100 \mathrm{~mm}$ の長方形の筒で，先端部は $15 \mathrm{~mm} \times$ $10 \mathrm{~mm}$ に絞つてある. 長さは $650 \mathrm{~mm}$ で下端は電磁ポ 


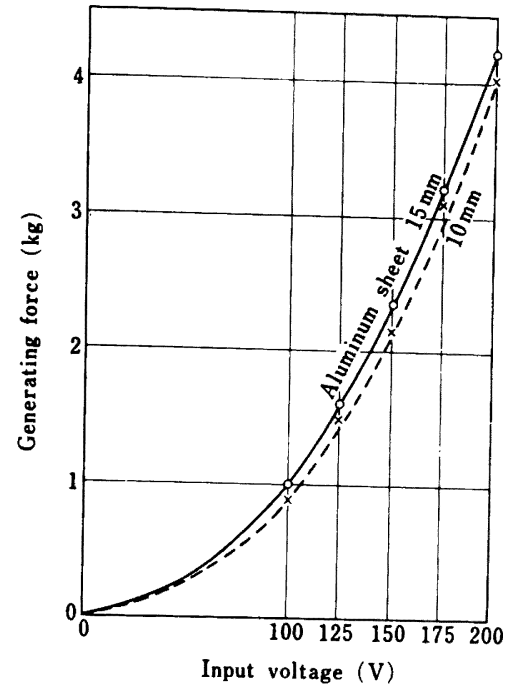

Fig. 8. Effect on generating force of thickness of metal sheet (clearance $42 \mathrm{~mm}$ ).

Table 2. Chemical composition of lautal (\%).

\begin{tabular}{c|c|c|c|c|c|c|c}
\hline $\mathrm{Al}$ & $\mathrm{Cu}$ & $\mathrm{Si}$ & $\mathrm{Mg}$ & $\mathrm{Zn}$ & $\mathrm{Fe}$ & $\mathrm{Mn}$ & $\mathrm{Ti}$ \\
\hline $\mathbf{8 8 . 7}$ & 1.40 & 6.99 & 0.53 & $1 \cdot 11$ & 1.05 & $0 \cdot 14$ & 0.09 \\
\hline
\end{tabular}

Table 3. Physical properties of lautal.

\begin{tabular}{|c|c|c|}
\hline \multicolumn{2}{|c|}{$\begin{array}{l}\text { Density (at } 20^{\circ} \mathrm{C} \text { ) } \\
\text { Specific heat (at } 100^{\circ} \mathrm{C} \text { ) } \\
\text { Thermal conductivity (at } 25^{\circ} \mathrm{C} \text { ) } \\
\text { Electric conductivity (at } 20^{\circ} \mathrm{C} \text { ) } \\
\text { Latent heat of fusion }\end{array}$} & $\begin{array}{l}2 \cdot 68 \mathrm{~g} / \mathrm{cm}^{2} \\
0 \cdot 23 \mathrm{cal} / \mathrm{g}^{\circ} \mathrm{C} \\
0 \cdot 36 \mathrm{cal} / \mathrm{cm} \\
\quad \mathrm{sec}^{\circ} \mathrm{C} \\
\left(4 \cdot 4 \times 10^{-6}\right)^{-1} \\
(\Omega \mathrm{cm})^{-1} \\
93 \mathrm{cal} / \mathrm{g}\end{array}$ \\
\hline $\begin{array}{l}\text { Melting } \\
\text { point }\end{array}$ & $\begin{array}{l}\text { Liquidus temperature } \\
\text { Solidus temperature }\end{array}$ & $\begin{array}{l}610^{\circ} \mathrm{C} \\
579^{\circ} \mathrm{C}\end{array}$ \\
\hline
\end{tabular}

ンブ最下端と一致するようにした.タンディッシュは直 径 $200 \mathrm{~mm}$ 高さ $350 \mathrm{~mm}$ の筒で底に長方形の穴があけ てあり，ストッパで閉められている。ここに高周波電気 炉によつて溶融したラウタルを上部の湯溜をとおして入 れる.タンディッシュはあらかじめ $400^{\circ} \mathrm{C}$ に加熱して おいた・タンディッシュ内のラウタル温度が $700^{\circ} \mathrm{C}$ に なつたときストッパーを開き，ノズルをとおして流し出 し下のるつぼでうけた. ノズル両面に配置した電磁ポン プにあらかじめ電力を供給しておき，ラウタルの自由落 下をおさえるむきに力を働らかせ，流量を制御した。制 御電圧は $50 ， 100 ， 150 ， 200 \mathrm{~V}$ 用いた。流量制御特性 はタンディッシュおよびるつぼに取りつけたロードセル の出力によつて算出した. ノズルを通過する際, 溶湯に

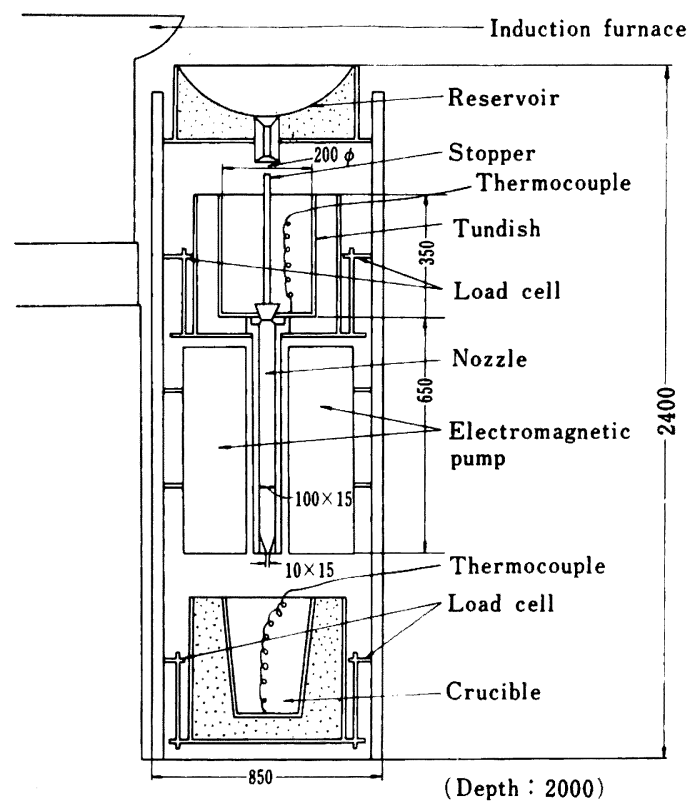

Fig. 9. Schematic drawing of equipment for experiment on flow rate control molten lautal.

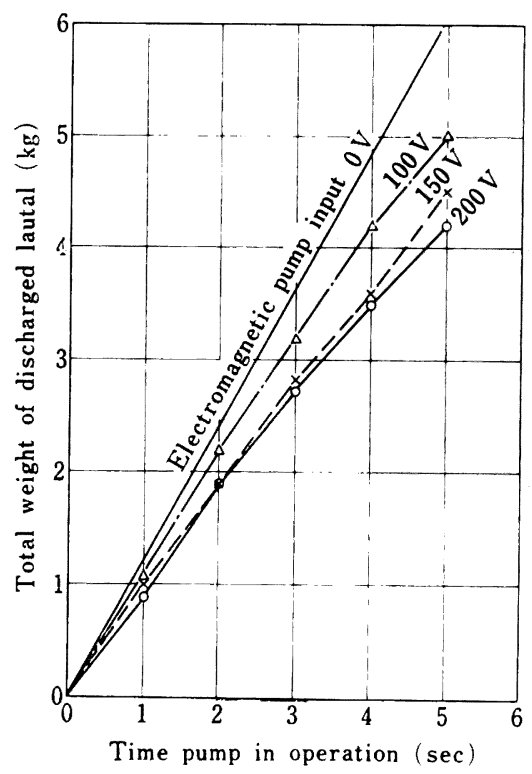

Fig. 10. Relationship between amount accumulated and time.

与える電磁ポンプの熱出力をもとめるためにノズル通過 の際の温度降下の測定も同時に行なつた.

\section{2 試験結果}

Fig. 10 は電磁ポンプの入力電主が，0，50，100，150, 


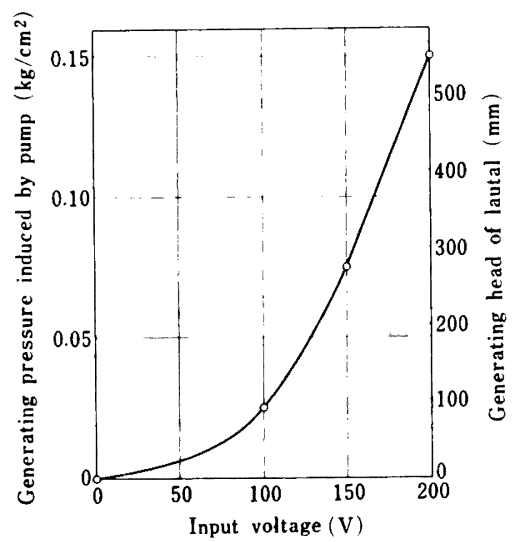

Fig. 11. Relationship between input and generating head of lautal or pressure.

$200 \mathrm{~V}$ の場合の流入時間と流量との関係である. 本実験 では, 溶融金属の自由落下と逆の向きに力を作用させて いたので, 電磁ポンプ作動区間では電压の高いほど溶融 金属は流れにくくなつていて流量が少なくなつた. Fig. 11は各電圧における発生圧力を示したものである.この グラフから, 固体アルミニウム板を使用して行なつた電 磁ポンプ特性試験の結果と同様に, 発生力は入力電生の 2 乗に比例して大きくなり，その最高値はラウタルのへ ッドで $550 \mathrm{~mm}$, 压力に直せば $0.15 \mathrm{~kg} / \mathrm{cm}^{2}$ に達した. ここで発生压力 $P\left(\mathrm{~kg} / \mathrm{cm}^{2}\right)$

ポンプの入力電压 $V$ (volt)

との間に

$$
\begin{aligned}
& P=a V^{2} \\
& a: \text { 定数 }
\end{aligned}
$$

の関係が成立するとして, $a$ の值を求めると

$$
a=3 \cdot 75 \times 10^{-6} \mathrm{~kg} / \mathrm{cm}^{2} \text { volt }^{2}
$$

となる・

Fig. 12 はポンプの入力と流量との関係を示す. 流量 は入力電压が 0 から $200 \mathrm{~V}$ に上がると $1 \cdot 20 \mathrm{~kg} / \mathrm{sec}$ か ら $0.83 \mathrm{~kg} / \mathrm{sec}$ に滅つている. すなわち溶融金属の流量 制御量は最大

$$
\frac{1 \cdot 20-0 \cdot 83}{1 \cdot 20} \times 100=30 \%
$$

行なわれたことを示している.

またノズルを通過した際の溶湯の温度降下量は電圧 0 のとき $70^{\circ} \mathrm{C}$ であつたが， $200 \mathrm{~V}$ では $20^{\circ} \mathrm{G}$ になつた。

このことは電磁ポンプの熱出力が温度降下を防げたた めと思われる. このときのポンプ内部 (挖線部) の温度 は最高 $50^{\circ} \mathrm{C}$ 程度であつた. なおこのポンプの撩線に用 いた絶縁銅線は $220^{\circ} \mathrm{C}$ までのものであり問題はなかつ

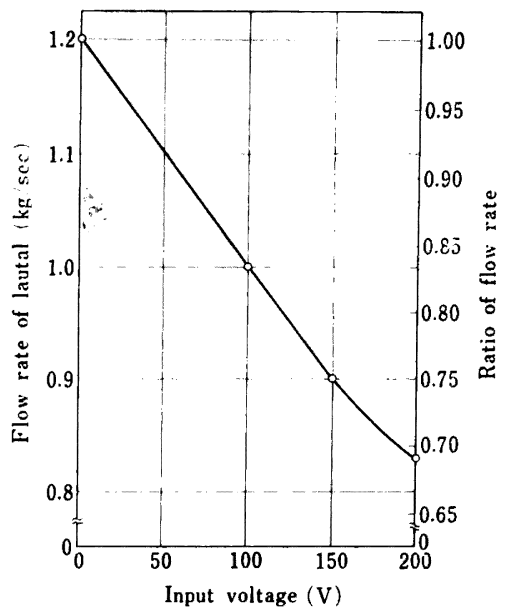

Fig. 12. Relationship between input and flow rate (Generating force induced by pump was applied to reduce the flow rate of free falling molten lautal).

た. 電磁ポンプを作動させているときの線電流はほとん ど変動がなかつた. 力率は電磁ポンプの入力側に $300 \mu \mathrm{F}$ のコンデンサを入れて改善した結果，これまで 25\%の 力率が約 75\% に上昇した.

\section{6. 電磁ポンプの出力計算}

誘導型電磁ポンプにより作り出される圧力は従来の理 論により次式で計算できる.

$$
\begin{aligned}
& P=10 \cdot 2 B_{\mathrm{m}}{ }^{2} \cdot \sigma \cdot f \cdot s \cdot l \cdot \tau \cdot k \times 10^{-16} \mathrm{~kg} / \mathrm{cm}^{2} \\
\text { ここに } &
\end{aligned}
$$

$$
\begin{aligned}
& B_{\mathrm{m}} \text { : 磁束密度 Gauss } \\
& \sigma: \text { 電気伝導度 }(\Omega \mathrm{cm})^{-1} \\
& f: \text { 周波数 } \mathrm{H}_{\mathrm{z}} \\
& s: \text { すべり } \\
& l: \text { ポンプの長さ } \mathrm{cm} \\
& \tau: \text { 磁極の間隔 } \mathrm{cm} \\
& k: \text { エッシ効果, 回路損失 }
\end{aligned}
$$

本実験に用いた電磁ポンプの性能を本式により計算す ると次のようになる.なお計算には Table 4 の数值を 用いた. この場合は電圧 $200 \mathrm{~V}$ のときの磁束密度を用 い,すベり，回路損失などはないものとした.

これによると

$$
P=0.3 \mathrm{~kg} / \mathrm{cm}^{2}
$$

となる・

実験結果 Fig. 11 によれば電圧 $200 \mathrm{~V}$ のときラウタ ルのヘッドとして $550 \mathrm{~mm}$ であり，これを $\mathrm{kg} / \mathrm{cm}^{2}$ に 
Table 4. Values and symbols used in calculation of pressure developed by electromagnetic pump.

\begin{tabular}{l|c|c|c}
\multicolumn{1}{c|}{ Factor } & Symbol & \multicolumn{2}{|c}{ Value } \\
\hline $\begin{array}{l}\text { Magnetic flux } \\
\text { density }\end{array}$ & $\mathrm{Bm}$ & 350 & Gauss \\
$\begin{array}{l}\text { Electric } \\
\text { conductivity }\end{array}$ & $\sigma$ & $\left(15 \times 10^{-6}\right)^{-1}$ & $(\Omega \mathrm{cm})^{-1}$ \\
$\begin{array}{l}\text { Frequency } \\
\text { Slip }\end{array}$ & $\mathrm{f}$ & 50 & $\mathrm{~Hz}$ \\
Pump length & $\mathrm{S}$ & 1 & \\
Pole pitch & $\tau$ & 55 & $\mathrm{~cm}$ \\
Coeff. of edge & $\mathrm{K}$ & $13 \cdot 2$ & $\mathrm{~cm}$ \\
$\quad$ effect & & 1 & \\
\hline
\end{tabular}

直せば $0.15 \mathrm{~kg} / \mathrm{cm}^{2}$ であるので，0.15/0.3×100=50\% となり，理論計算より小さくなつた。これは理論計算で はすべりおよび回路損失を無視したことや，実際にはそ の他の損失があることによるものと考えられる.

\section{7. 総括}

(1) 3 相 $200 \mathrm{~V}$ 平面型直線唀導電礠ホンプを試作し, 磁束密度，固体金属人の発生力，溶融金属の流量制御試 験を行なつた.

(2) Table 1 および Fig. 9 に示す容量のポンプを用 い，ラウタルをノズルから垂直に流し出す場合の流量制 御を行なつた，その結果最大 $30 \%$ の流量が制御される ことがわかつた.

(3)この結果に対し従来の理論式を用いて計算した が，実験によるポンプ出力は理論の約 $50 \%$ となつた. これは理論式に対する仮定の不備と実験上の諸損失によ るものと考えられる. しかし本結果よりも電磁ポンプ設 計資料を得ることができた

(4) 鋳鉄についても同装置で実験を行なつたが，ホン
プ出力が足りず制御できなかつた．錚鉄の場合は電気伝 導度がラウタルの約 $\frac{1}{20}$ となるため, 理論式からもわか るようにホンプ容量を增さないと玨力をだすことはでき ない.容量を電気伝導度に比例して大きくすればラウタ ル同様制御が可能であると思われる.

\section{8. と がき}

本研究の実施に当たつて，実験にたずさわられた井 原, 来村, 永島の諸君, 製作に協力された会田君を始め 機械実験所の諸君に厚く御礼を申し上げる．また本研究 に協力をいただいた久保田鉄工株式会社に厚く感謝の意 を表する次第である.

\section{文献}

1) L. A. BEPTE: Electromagnetic Transport of Liquid Metal. Publisher Metallurgy (1965)

2 ) L. A. BEPTE: Electromagnetic Pouring and Treatment of Liquid Metal. Publisher Metallurgy (1967)

3 ) O. TEDDER: Electromagnetic pumping of molten cast. Iron and Steel, 35 (1962), pp. 317

4 ) Von Gerhard, $W$. Seulen und $A$. von Strack in Remscheid: Das Electromagnetische Forden und Dosieren von Flussigen Metallen. Giesserei 56 (1969), 2 Jan, 1

5 ) $R$. S. BAKER: A new electromagnetic pump for liquid metals. ASME Paper 63-WA-92

6) A. Yanagizawa: Electromagnetic pump. Kinzoku (1968-10) (in Japanese)

7) N. M. OкнRемenкo: Electromagnetic phenomena in flat type induction pumps for molten metal. ARS Journal Supplement 1442-1448 Translated from Electrichestvo (electrily), No 3 48-54 (March 1960). Translated by primary Sources, New York 